\title{
THE IDENTIFICATION OF CLOSE RELATIVES OF THE DECEASED SUSPECT OR ACCUSED IN CRIMINAL PROCEEDINGS: THE PROBLEMS OF THE LEGAL REGULATION AND INTERACTION
}

\author{
Kristina A. Trifonova \\ Academy of the Ministry of Internal Affairs of Russia, Volgograd, Russian Federation \\ Mikhail A. Shmatov \\ Academy of the Ministry of Internal Affairs of Russia, Volgograd, Russian Federation \\ Vadim N. Perekrestov \\ Judicial District No. 47, Svetly Yar, Volgograd Region, Russian Federation
}

\begin{abstract}
Introduction: the termination of a criminal case or refusal to initiate a criminal case on a non-rehabilitative basis, provided for in paragraph 4, part 1, Article 24 of the Code of Criminal Procedure of the Russian Federation, will have a certain degree of specificity in the production of procedural actions. A sign of this type of proceedings is the appearance of a special category of subjects of criminal procedural relations - close relatives of the deceased person, who can initiate further investigation of the criminal case and its consideration in court in order to rehabilitate the deceased suspect or accused. These subjects are involved in the plane of legal relations in connection with the presence of their "legitimate interest", both of a property and non-property nature. A detailed study of the criminal procedure status of a person against whom the criminal prosecution was carried out, but he was not given the status of a suspect or accused, is due to the need to establish the circle of his close relatives. The effectiveness of this activity depends both on the successful interaction of the subject of the investigation with the body of inquiry and other state bodies, and on the legal regulation of the situation in criminal proceedings of close relatives and other interested persons of the deceased. The purpose of the study is to analyze the legal status of the deceased person not only at the stage of procedural verification, but also at the stage of preliminary investigation, as well as to suggest the ways to solve problems, related to the involvement of close relatives and other interested persons of the deceased in the investigation process, including through $\vec{\widetilde{ }}$ the use of various forms of interaction of the subject of the investigation with the body of inquiry and the state ㄱ. bodies. Methods: in the course of the study, the general and specific scientific methods were used, namely: comparative research, system analysis and logical-legal. Results: the paper analyzes the current regulatory regulation of the legal status of a deceased person during a procedural check before making a decision to refuse to initiate a criminal case, and provides a comparative legal analysis of similar legal provisions under the legislation . of some foreign countries. The problems associated with the moment when it is necessary to obtain the consent of close relatives for making a decision in accordance with paragraph 4 of part 1 of the article are identified. 24 of the Code of Criminal Procedure of the Russian Federation, the directions and conditions of the activity of the investigative body in connection with the adoption of this decision are defined. It is indicated that the circle of related persons whose opinion needs to be clarified is not defined in the law. In this regard, it is proposed to rely on the position of the Constitutional Court of the Russian Federation and find out the opinion primarily of close relatives, the establishment of which depends on the successful application of various forms of interaction. Conclusions: the legislative recommendations are proposed to improve the legal status of a deceased person who has not yet been given the status of a suspect or accused, but in relation to whom the criminal prosecution was carried out. The paper analyzes in detail the activities of the investigation body to identify close relatives in order to clarify their opinion on the decision made in accordance with paragraph 4, part 1, Article 24 of the Criminal Procedure Code of the Russian Federation. The recommendations on the organization of interaction aimed at identifying the specified participants in the criminal process are given.

Key words: death of a suspect or accused, termination of a criminal case, refusal to initiate a criminal case, close relatives, interaction.
\end{abstract}


Citation. Trifonova K.A., Shmatov M.A., Perekrestov V.N. The Identification of Close Relatives of the Deceased Suspect or Accused in Criminal Proceedings: The Problems of the Legal Regulation and Interaction. Legal Concept $=$ Pravovaya paradigma, 2021, vol. 20, no. 2, pp. 90-99. (in Russian). DOI: https://doi.org/10.15688/lc.jvolsu.2021.2.12

УДК 343.135

Дата поступления статьи: 10.03.2021

ББК 67.410 .2 Дата принятия статьи: 06.04.2021

\title{
УСТАНОВЛЕНИЕ БЛИЗКИХ РОДСТВЕННИКОВ УМЕРШЕГО ПОДОЗРЕВАЕМОГО ИЛИ ОБВИНЯЕМОГО ПРИ ПРОИЗВОДСТВЕ ПО УГОЛОВНОМУ ДЕЛУ: ПРОБЛЕМЫ ПРАВОВОЙ РЕГЛАМЕНТАЦИИ И ВЗАИМОДЕЙСТВИЯ
}

\author{
Кристина Алексеевна Трифонова \\ Волгоградская академия МВД России, г. Волгоград, Российская Федерация \\ Михаил Андреевич Шматов \\ Волгоградская академия МВД России, г. Волгоград, Российская Федерация
}

\section{Вадим Николаевич Перекрестов}

Судебный участок № 47, р. п. Светлый Яр, Волгоградская область, Российская Федерация

Введение: прекращение уголовного дела либо отказ в возбуждении уголовного дела по нереабилитирующему основанию, предусмотренному п. 4 ч. 1 ст. 24 УПК РФ, имеет свою специфику при производстве процессуальных действий. Признаком данного вида производства становится появление особой категории субъектов уголовно-процессуальных отношений - близких родственников умершего лица, которые могуг инициировать дальнейшее расследование уголовного дела и рассмотрение его в суде с целью реабилитации умершего подозреваемого или обвиняемого. Указанные субъекты вовлекаются в плоскость правоотношений в связи с наличием у них «законной заинтересованности» как имущественного, так неимущественного характера. Детальная проработка уголовно-процессуального положения лица, в отношении которого осуществлялось уголовное преследование, но без придания ему статуса подозреваемого или обвиняемого, обусловлена необходимостью установления круга его близких родственников. Эффективность данной деятельности зависит как от успешного взаимодействия субъекта расследования с органом дознания и другими государственными органами, так и от правового регулирования положения в уголовном судопроизводстве близких родственников и иных заинтересованных лиц умершего. Цель исследования заключается в анализе правового положения умершего лица не только на этапе процессуальной проверки, но и на стадии предварительного расследования, а также предложение путей решения проблем, связанных с вовлечением в процесс расследования близких родственников и иных заинтересованных лиц умершего, в том числе посредством использования возможностей различных форм взаимодействия субъекта расследования с органом дознания и государственными органами. В ходе проведения данного исследования использованы общие и частные научные методы: сравнительное исследование, системный анализ и логико-юридический. Результаты: проанализирована действующая нормативная регламентация правового положения умершего лица в ходе процессуальной проверки перед принятием решения об отказе в возбуждении уголовного дела, проведен сравнительно-правовой анализ схожих правовых установлений по законодательству некоторых зарубежных государств. Обозначены проблемы, связанные с моментом возникновения необходимости получать согласие близких родственников для принятия решения в порядке п. 4 ч. 1 ст. 24 УПК РФ, определены направления и условия деятельности органа расследования в связи с принятием указанного решения. Указывается, что круг родственных лиц, чье мнение необходимо выяснять, не определен в законе. В связи с этим предлагается опираться на позицию Конституционного Суда РФ и выяснять мнение в первую очередь близких родственников, установление которых зависит от успешного применения различных форм взаимодействия. Выводы: предложены законодательные рекомендации по совершенствованию правового положения умершего лица, которому еще не придан статус подозреваемого или обвиняемого, но в отношении которого осуществлялось уголовное преследование. Детально проанализирована деятельность органа расследования по установлению близких родственников с целью выяснения их мнения по поводу принимаемого решения в порядке п. 4 ч. 1 ст. 24 УПК РФ. Даны рекомендации по организации взаимодействия, направленного на установление указанных участников уголовного процесса. 
Ключевые слова: смерть подозреваемого или обвиняемого, прекращение уголовного дела, отказ в возбуждении уголовного дела, близкие родственники, взаимодействие.

Цитирование. Трифонова К. А., Шматов М. А., Перекрестов В. Н. Установление близких родственников умершего подозреваемого или обвиняемого при производстве по уголовному делу: проблемы правовой регламентации и взаимодействия // Legal Concept = Правовая парадигма. - 2021. - Т. 20, № 2. - C. 90-99. - DOI: https://doi.org/10.15688/lc.jvolsu.2021.2.12

\section{Введение}

Нормативная регламентация порядка отказа в возбуждении уголовного дела и прекращения уголовного дела (уголовного преследования) в связи со смертью подозреваемого (обвиняемого), предусмотренная п. 4 ч. 1 ст. 24, п. 2. ч. 1 ст. 27, п. 1 ст. 254 УПК РФ, малоинформативная.

В общем понимании положения, закрепленные в п. 4 ч. 1 ст. 24 УПК РФ, распространяют свое действие на два вида деятельности органа расследования в досудебном производстве, связанных с прекращением либо продолжением производства по уголовному делу. Во втором случае инициатива может исходить от лиц, состоящих в родстве с умершим лицом, с целью возможной реабилитации. Принятие одного из обозначенных решений осуществляется либо на этапе процессуальной проверки сообщения о преступлении, либо на стадии предварительного расследования. В любом случае решение принимается в отношении конкретного лица.

Такая «скудность» нормативной регламентации влечет не только закономерные вопросы у правоприменителей, но и порождает дискуссию в научном сообществе. Наиболее актуальные проблемы связаны как с процессуальным статусом лица, в отношении которого принимается решение в порядке п. 4 ч. 1 ст. 24 УПК РФ либо продолжается расследование, так и с процедурой вовлечения в плоскость уголовнопроцессуальных отношений близких родственников и иных заинтересованных лиц умершего. В связи с неопределенным кругом таких лиц и сложностями при их установлении возрастает роль взаимодействия следователя или дознавателя с органом дознания и другими государственными органами.

\section{Уголовно-процессуальный статус умершего лица}

Среди множества нерешенных вопросов в первую очередь обращает на себя внимание наименование процессуального статуса лица, в отношении которого может быть принято одно из указанных процессуальных решений - только подозреваемый или обвиняемый. Может сложиться ошибочное представление, что «если факт смерти будет установлен на этапе проверки сообщения о преступлении, отказаться от предварительного расследования следователь не может» [10]. Придать такой статус на этом этапе невозможно, даже несмотря на то что фактически в противоположной ситуации уголовное дело было бы возбуждено в отношении конкретного лица. На этапе процессуальной проверки речь может идти, как указано в ч. 1.1 ст. 144 УПК РФ, только о лицах, участвующих в производстве процессуальных действий или участниках проверки сообщения о преступлении, но эти обозначения слишком «размытые». Конституционный Суд Российской Федерации (далее - КС РФ) относительно конституционности рассматриваемой нормы употребляет универсальное наименование умершего лица. В силу действия принципа презумпции невиновности используется наиболее общее наименование умершего, применяемое ко всем основаниям отказа в возбуждении уголовного дела или его прекращения на досудебных стадиях «лицо, привлекавшееся к участию в уголовном судопроизводстве ввиду выдвижения против него подозрения или обвинения» [14].

Уголовно-процессуальное законодательство ряда зарубежных государств разрешило схожую проблему, предусмотрев нормативное определение такого участника. Например, в п. 12.1 ст. 6 Уголовно-процессуального кодекса Республики Беларусь (далее - УПК РБ) дано определение «лица, подлежащего привлечению в качестве подозреваемого, обвиняемого», то 
есть «это лицо, умершее после совершения преступления до возбуждения в отношении его уголовного дела или в период предварительного расследования преступления, если в отношении этого лица уголовное дело не возбуждалось, но имеются достаточные данные, указывающие на совершение им этого преступления» [11].

Уголовно-процессуальное законодательство Республики Казахстан (далее - УПК РК) использует обобщенное понятие «умерший» (п. 11 ч. 1 ст. 35). Если же в отношении лица имелось первичное подозрение без придания ему статуса подозреваемого или обвиняемого, то такой участник именуется как «свидетель, имеющий право на защиту как лицо, совершившее уголовное правонарушение» (ч. 5 ст. 78 УПК РК) [12].

В связи со сказанным стоит поддержать многочисленные позиции ученых-процессуалистов о придании более четкого статуса не только лицу, в отношении которого проводится проверка [4, с. 109; 5, с. 137], но и умершему лицу $[1 ; 7]$ до возбуждения уголовного дела либо после, если уголовное дело было возбуждено по факту и лицу до его смерти не был придан статус подозреваемого или обвиняемого, но собранными доказательствами установлена его причастность к совершению преступления. В настоящий момент, если решение в порядке п. 4 ч. 1 ст. 24 УПК РФ будет приниматься на этапе возбуждения уголовного дела, наиболее верным представляется указание в постановлении об отказе в возбуждении уголовного дела только фамилии, имени и отчества умершего лица без какого-либо процессуального статуса. В том случае, если от близких родственников поступит ходатайство о возбуждении уголовного дела с целью реабилитации умершего, уголовное дело должно быть возбуждено в отношении конкретного лица.

\section{Некоторые аспекты правового} регулирования и взаимодействия при установлении близких родственников умершего подозреваемого

\section{или обвиняемого}

\section{и иных заинтересованных лиц}

Наиболее обширный круг проблем связан с вовлечением в плоскость уголовно-про- цессуальных отношений близких родственников и иных заинтересованных лиц умершего. В первую очередь обращает на себя внимание примечание к п. 4 ч. 1 ст. 24 УПК РФ, носящее односторонний характер, в виде необходимости получения согласия близких родственников только при решении вопроса о прекращении уголовного дела. Это также исходит из первоначальной позиции КС РФ, изложенной в резолютивной части постановления от 14.07.2011 № 16-П [14]. В одном из последних решений [17] КС РФ указал на схожесть прав и законных интересов близких родственников как при прекращении уголовного дела по п. 4 ч. 1 ст. 24 УПК РФ, так и при отказе в возбуждении уголовного дела. При этом КС РФ указал на право близких родственников не только отстаивать свою позицию по вопросу невозможности отказа в возбуждении уголовного дела, но и по вопросу о возможности принятия такого решения.

Выяснение позиции близких родственников должно осуществляться не только в связи с прекращением уголовного дела (преследования), но и при решении вопроса субъектом расследования об отказе в возбуждении уголовного дела. Волеизъявление близких родственников о продолжении производства по уголовному делу может быть оформлено в виде отдельного документа, например письменного ходатайства (заявления) о несогласии с отказом в возбуждении уголовного дела, мотивация такого заявления - реабилитация умершего, основания для которой возможно установить только при осуществлении полноценного расследования. Если смерть лица наступает после возбуждения уголовного дела, то позиция близкого родственника может быть отражена в заявлении или ходатайстве с указанием о необходимости продолжить расследование по уголовному делу с аналогичным доводом.

Если речь идет об этапе возбуждения уголовного дела и из материалов процессуальной проверки следует вывод о первичном подозрении конкретного лица в совершении преступления, то орган расследования мог бы принять решение о возбуждении уголовного дела в отношении конкретного лица, но по объективным причинам сделать этого не может по причине его смерти. После возбужде- 
ния уголовного дела осуществляется уголовное преследование в связи с наличием подозрения либо дальнейшее преследование конкретного лица в совершении преступления и происходит доказывание факта совершения преступления данным лицом. Однако продолжение доказывания его виновности невозможно по причине его смерти.

И в том, и в другом случае необходимо выяснить мнение близких родственников умершего лица. Если при этом по вопросу принятия решения об отказе в возбуждении уголовного дела поступят возражения, то уголовное дело должно быть возбуждено в отношении конкретного лица, а уголовное преследование будет продолжено. Значит, дальнейшая процессуальная деятельность органа расследования после возбуждения уголовного дела в отношении умершего (конкретного лица) будет схожа с той, что осуществляется в случае поступления возражения от близких родственников при решении вопроса о прекращении уголовного дела в отношении подозреваемого или обвиняемого, то есть на стадии предварительного расследования. Если органом расследования в дальнейшем будут установлены основания для реабилитации, то должно быть принято соответствующее решение. В противном случае дело должно быть направлено в суд для рассмотрения в общем порядке. Таким образом, цель такой деятельности для близких родственников - это реабилитация, а для органа расследования - полноценное расследование для установления всех обстоятельств совершенного преступления.

Как видно, деятельность органа расследования, связанная с применением п. 4 ч. 1 ст. 24 УПК РФ, может развиваться в двух направлениях, что обусловлено выяснением мнения близких родственников умершего лица: отказ от дальнейшего производства по уголовному делу, в том числе уголовного преследования, или его продолжение.

Условия для продолжения данной деятельности также идентичны для указанных выше этапов: во-первых, это наличие достоверных сведений о смерти лица, в отношении которого имеется подозрение или обвинение в совершении преступления; во-вторых, при предварительной проверке сообщения о преступлении или при расследовании уголовного дела должны быть получены доказательства того, что преступление совершено именно тем лицом, которое скончалось; в-третьих, обеспечение прав и законных интересов близких родственников умершего.

Факт смерти, как отмечается в научных исследованиях, обычно подтверждается сведениями, полученными из органов записи актов гражданского состояния, свидетельством о смерти, справкой о наличии записи акта о смерти [2]. Основанием для выдачи указанных документов в том числе может являться решение суда о признании гражданина умершим в порядке гл. 30 Гражданско-процессуального кодекса РФ.

Следует отметить, что выполнить второе условие на этапе возбуждения уголовного дела проблематично в силу ограниченности органа расследования в доказывании, поэтому стоит согласиться с мнением О.И. Цоколовой и В.М. Карпенко, что «в подобных ситуациях уголовное дело должно быть возбуждено и расследовано, а отказ в возбуждении уголовного дела в связи со смертью лица, совершившего преступление (п. 4 ч. 1 ст. 24 УПК РФ) не может быть рекомендован следователям, дознавателям ОВД» [9]. Однако, если рассматривать ситуацию, когда преступление совершено в условиях очевидности, а смерть лица наступила при задержании или, например, по уголовным делам о дорожно-транспортных происшествиях, такое решение органа расследования представляется допустимым. В обозначенных случаях полученные органом расследования сведения, позволяющие сделать вывод о субъекте преступления, в обычных условиях были бы достаточны для возбуждения уголовного дела в отношении конкретного лица и придания ему соответствующего статуса подозреваемого.

Относительно третьего условия стоит обратить внимание на ряд пробелов законодательного регулирования и проблем, возникающих в практической деятельности. Реализация данного условия тесно связана с принципом презумпции невиновности. Проблема прекращения уголовного дела по нереабилитирующему основанию без выяснения мнения обвиняемого была отмечена в Постановлении КС РФ от 28.10.1996 № 18-П [13]. В дальнейшем Постановлением КС РФ от 14.07.2011 
№ 16-П [14] были признаны неконституционными положения п. 4 ч. 1 ст. 24 УПК РФ, позволяющие прекратить уголовное дело в связи со смертью подозреваемого (обвиняемого) без согласия его близких родственников.

До настоящего времени нерешенным остается вопрос, мнение какого именно родственного лица умершего относительно принимаемого решения необходимо выяснять. В юриспруденции в зависимости от отрасли права имеется множество примеров урегулирования родственных уз. В научном сообществе предлагается применять по аналогии положения ч. 8 ст. 42 УПК РФ и выяснять мнение близких родственников и (или) близких лиц, а при их отсутствии - родственников [6, с. 138]. Однако сказанное необходимо рассматривать через призму позиции КС РФ о необходимости выяснения мнения заинтересованных лиц, прежде всего, близких родственников умершего [14]. В дальнейших решениях КС РФ также акцентирует внимание на выяснении мнения именно близких родственников. В случае получения точки зрения только лишь одного близкого родственника [3, с. 120], несмотря на существенную процессуальную экономию сил органа расследования, означало бы нарушение права указанных лиц на доступ к правосудию и исключало бы защиту собственных чести и достоинства.

В связи с изложенным следователю (дознавателю) в кратчайшие сроки надлежит провести комплекс действий по установлению всех близких родственников (п. 4 ст. 5 УПК РФ) с целью их уведомления о необходимости выразить свое мнение относительно принимаемого решения. Особенно усложняется ситуация, если умершее лицо при жизни не было допрошено и минимальные сведения о его личности, в том числе родственных связях, не получены.

Непременным и эффективным средством решения данной тактической задачи является использование возможностей взаимодействия не только с различными государственными органами, но и органом дознания, что обеспечивает постоянный контакт при расследовании преступлений [8, с. 167].

Взаимодействие с государственными органами осуществляется посредством направления запросов об истребовании инфор- мации. В территориальных многофункциональных центрах возможно получение сведений: о наличии у умершего лица детей, о семейном положении и родителях [форма № 1П «Заявление о выдаче (замене) паспорта»], о составе семьи. Информация о факте рождения детей и родителях также может быть получена в органах записи актов гражданского состояния. Возможно получение значимой информации прошлых лет из фондов архивов при администрации территориального субъекта. В случае, если при допросе свидетелей (соседи, сослуживцы) удалось установить частичные данные о близких родственниках умершего лица, то с целью получения полных анкетных данных, адреса места жительства целесообразно направить запрос в отдел адресносправочной работы соответствующего территориального управления по вопросам миграции.

Конечно, в контексте рассматриваемой деятельности исход, связанный с прекращением уголовного дела, вряд ли относится к положительным показателям оценки следственного подразделения, но и не означает отрицательного результата в связи с объективной причиной прекращения уголовного дела. Несмотря на то что намерения субъекта расследования не совпадают с ожиданиями органа дознания, направление письменного поручения является основным видом взаимодействия при установлении близких родственников умершего лица. В содержании письменного поручения должна быть изложена необходимая для исполнителя информация об умершем лице и просьба провести мероприятия, направленные на установление и дальнейшее предоставление информации о близких родственниках, с перечислением их категории в соответствии с п. 4 ст. 5 УПК РФ. В случае определения таковых необходимо обязать их явкой в орган расследования. Исполнителем такого поручения, например, может выступать участковый уполномоченный полиции.

В результате взаимодействия может появиться информация о близких родственниках, проживающих в других субъектах РФ. В таком случае понадобится направление отдельного поручения, исполнителем которого может выступить следователь другого территориального следственного подразделения. При направлении подобного поручения целесооб- 
разно обратиться с просьбой о допросе близкого родственника на предмет его взаимоотношений в прошлом с умершим и выяснения мнения в связи с возможным принятием решения в порядке п. 4 ч. 1 ст. 24 УПК РФ с получением соответствующего ходатайства (заявления).

Не содержится в УПК РФ алгоритма действий для органа расследования и в том случае, если близкие родственники умершего отсутствуют, либо категорически отказываются от участия в уголовном деле, в связи с чем затруднительно получить волеизъявление относительно принимаемого решения. Следует предположить, если близкий родственник умершего лица, когда он надлежащим образом уведомлен о необходимости прибыть к субъекту расследования и выразить свое мнение по поводу планируемого решения, игнорирует участие в уголовном деле, то это означает его согласие с любым принимаемым решением в порядке п. 4 ч. 1 ст. 24 УПК РФ, то есть предполагает отсутствие у него интереса к возможным правовым последствиям. В данном случае видится презумпция согласия близких родственников умершего. Однако неявка и нежелание близкого родственника умершего выражать согласие либо несогласие на прекращение уголовного дела порождают необоснованное затягивание расследования. Представляется возможным использовать для решения указанной проблемы положения уголовно-процессуального законодательства Республики Беларусь (ч. 1 ст. 468.14 УПК Республики Беларусь) [3] и установить конкретный срок выражения мнения близкими родственниками умершего лица, например не позднее 3 суток с момента получения уведомления.

Продолжение же производства по уголовному делу в случае отсутствия документального подтверждения позиции указанными лицами ставит под сомнение реализацию рассматриваемой нормы закона. При этом орган расследования исходит из того, что к моменту выяснения позиции близких родственников получено достаточно доказательств, обосновывающих причастность умершего к совершенному преступлению.

Противоположная ситуация может складываться, когда у умершего подозреваемого или обвиняемого несколько близких родственников с различными мнениями относительно дальнейшего производства по уголовному делу. И вновь обратимся к позиции КС РФ. Так, в определении КС РФ от 10 марта 2016 г. № 456-О указывается, что субъект расследования должен продолжить производство по делу в отношении умершего подозреваемого или обвиняемого, несмотря на согласие одного из близких родственников с решением о прекращении уголовного дела, если в то же время имеется возражение другого близкого родственника против принятия такого решения в порядке [15].

Таким образом, субъект расследования, следуя контексту определения КС РФ, обязан предпринять все меры к установлению близких родственников умершего подозреваемого (обвиняемого), а также уведомить их о принимаемом решении, тем самым обеспечив право настаивать на продолжении производства по уголовному делу. Такое же правило должно распространяться и на стадию возбуждения уголовного дела. Только при соблюдении указанных условий будет обеспечена защита прав умершего лица на защиту чести, достоинства и доброго имени.

\section{Выводы}

Результатом обозначенной выше деятельности будет являться допуск к участию в уголовном деле одного из близких родственников с учетом мнения лица, которое изъявит желание представлять интересы умершего. Данное решение следователь или дознаватель должен оформить постановлением о допуске представителя умершего подозреваемого (обвиняемого). В этом ракурсе следует еще раз подчеркнуть важность придания статуса лицу на этапе возбуждения уголовного дела. Если исходить из того, что фактически органом расследования осуществлялось уголовное преследование в связи с наличием подозрения в отношении конкретного лица и был доказан факт совершения преступления данным лицом, однако продолжение доказывания виновности данного лица невозможно в связи с его смертью, то логично на этапе возбуждения уголовного дела допускать представителя умершего лица, 
подлежащего привлечению к уголовной ответственности.

Проанализированная проблематика правового положения умершего лица и его правопреемников позволяет отметить особый характер производства по уголовному делу в целях его реабилитации. Данный вид досудебной деятельности органа расследования представляет собой особое производство, характеризующееся переходом некоторых прав умершего лица его близким родственникам. Инициатива продолжения производства исходит в таком случае от близких родственников и не может игнорироваться следователем (дознавателем). Если же органом расследования получено недостаточно доказательств о подозрении (виновности) умершего лица, то отказ в возбуждении уголовного дела или его прекращение, в том числе преследование, недопустимо. Таким образом, продолжение расследования зависит от воли стороны защиты в лице правопреемника умершего лица. Решение обозначенных в настоящей статье проблем, возникающих в деятельности субъекта расследования, обеспечит детальная проработка процессуального статуса умершего лица и его близких родственников и иных заинтересованных лиц на всех этапах производства по уголовному делу. Предложенные рекомендации по использованию возможностей взаимодействия при расследовании преступлений позволят более эффективно осуществить деятельность по установлению всех близких родственников с целью их уведомления о необходимости выразить свое мнение относительно принимаемого решения.

\section{СПИСОК ЛИТЕРАТУРЫ}

1. Григорьев, В. Н. Обретение лицом уголовно-процессуального статуса подозреваемого: в чем проблемы? / В. Н. Григорьев // Вестник Московского университета МВД России. - 2016. - № 4. C. 41-46.

2. Ларин, Е. Г. Особенности производства по уголовному делу в случае смерти подозреваемого (обвиняемого) / Е. Г. Ларин // Законодательство и практика. - 2016. - № 2. - С. 13-16.

3. Корчагина, Л. И. Особенности прекращения уголовного преследования в отношении умерших (в свете реализации права на защиту) / Л. И. Корча- гина // Вестник Московского университета МВД России. - 2013. - № 5. - С. 117-121.

4. Овсянников, И. В. Уголовное преследование конкретного лица и проблемы обеспечения его права на защиту при проверке сообщения о преступлении / И. В. Овсянников // Вестник Волгоградской академии МВД России. -2018. - № 2. - С. 107-112.

5. Павлов, А. В. Развитие правового статуса подозреваемого в уголовном судопроизводстве России / А. В. Павлов // Вестник Волгоградской академии МВД России. - 2018. - № 1. - С. 134-141.

6. Патрушева, А. А. Уголовно-процессуальные правоотношения, возникающие в связи со смертью участников уголовного судопроизводства : дис. ... канд. юрид. наук / Патрушева Алена Александровна. - Омск, 2020.-257 с.

7. Сопнева, Е. В. Заподозренный как способ выражения подозрения / Е. В. Сопнева // Актуальные проблемы российского права. - 2014. - № 7. C. $1474-1480$.

8. Хоршева, В. С. О некоторых аспектах взаимодействия следователя, дознавателя с оперативными службами органов внутренних дел в ходе расследования преступлений / В. С. Хорошева // Вестник Волгоградской академии МВД России. - 2019. № 1. - С. 166-173.

9. Цоколова, О. И. Досудебное производство в отношении умершего подозреваемого (обвиняемого) / О. И. Цоколова, В. М. Карпенко // Вестник Московского университета МВД России. - 2016. № 4. - С. 125-130.

10. Шипунова, О. В. Смерть лица, совершившего преступление, как основание отказа в возбуждении уголовного дела / О. В. Шипунова // Юридическая наука и правоохранительная практика. 2015. - № 2. - С. 189-195.

11. Уголовно-процессуальный кодекс Республики Беларусь от 16.07.1999 № 295-3 (с изменениями и дополнениями по состоянию на 17.07.2020) // ИС Параграф «Юрист». - Электрон. текстовые дан. - Режим доступа: https://o№lioo.zako№.kz/ docume№t/?doc_id=30414958. - Загл. с экрана.

12. Уголовно-процессуальный кодекс Республики Казахстан от 04.07.2014 № 231-V (с изменениями и дополнениями по состоянию на 02.01.2021) // ИС Параграф «Юрист». - Электрон. текстовые дан. - Режим доступа: https://ooli№e.zako№.kz/m/ docume№t?doc_id=31575852. - Загл. с экрана.

13. По делу о проверке конституционности статьи 6 Уголовно - процессуального кодекса РСФСР в связи с жалобой гражданина О.В. Сушкова : постановление КС РФ от 28.10.1996 № 18-П // Доступ из справ.-правовой системы «КонсультантПлюс».

14. По делу о проверке конституционности положений пункта 4 части первой статьи 24 и пункта 1 статьи 254 Уголовно-процессуального кодекса Рос- 
сийской Федерации в связи с жалобами граждан С.И. Александрина и Ю.Ф. Ващенко : постановление КС РФ от 14.07.2011 № 16-П // Доступ из справ.правовой системы «КонсультантПлюс».

15. Об отказе в принятии к рассмотрению жалобы гражданина Захарова Андрея Валентиновича на нарушение его конституционных прав пунктом 4 части первой статьи 24 Уголовно-процессуального кодекса Российской Федерации : определение КС РФ от 10.03.2016 № 456-О // Официальный сайт КС РФ. Решения КС РФ. - Электрон. текстовые дан. - Режим доступа: http://doc.ksrf.ru/decision/ KSRFDecision228376.pdf. - Загл. с экрана.

16. Об отказе в принятии к рассмотрению жалобы граждан Жиделева Дмитрия Константиновича и Кожевникова Юрия Ивановича на нарушение их конституционных прав пунктом 4 части первой статьи 24 Уголовно-процессуального кодекса Российской Федерации : определение КС РФ от 29.09.2020 г. № 1944-О // Официальный сайт КС РФ. Решения КС РФ. - Электрон. текстовые дан. Режим доступа: http://doc.ksrf.ru/decision/ KSRFDecision497485.pdf. - Загл. с экрана.

\section{REFERENCES}

1. Grigorev V.N. Obretenie litsom ugolovnoprotsessualnogo statusa podozrevaemogo: $\mathrm{v}$ chem problemy? [Acquiring the Criminal Procedure Status of a Suspect: What are the Problems?]. Vestnik Moskovskogo universiteta MVD Rossii, 2016, no. 4, pp. 41-46.

2. Larin E.G. Osobennosti proizvodstva po ugolovnomu delu v sluchae smerti podozrevaemogo (obviniaemogo) [Features of Criminal Proceedings in the Event of the Death of a Suspect (Accused)]. Zakonodatelstvo i praktika, 2016, no. 2, pp. 13-16.

3. Korchagina L.I. Osobennosti prekrashcheniia ugolovnogo presledovaniia $\mathrm{v}$ otnoshenii umershikh (v sveterealizatsii prava na zashchitu) [Features of the Termination of Criminal Prosecution Against the Deceased (In the Light of the Realization of the Right to Defense)]. Vestnik Moskovskogo universiteta MVD Rossii, 2013, no. 5, pp. 117-121.

4. Ovsiannikov I.V. Ugolovnoe presledovanie konkretnogo litsa i problemy obespecheniia ego prava na zashchitu pri proverke soobshcheniia o prestuplenii [Criminal Prosecution of a Particular Person and the Problems of Ensuring His Right to Protection when Verifying a Report of a Crime]. Vestnik Volgogradskoi akademii MVD Rossii, 2018, no. 2, pp. 107-112.

5. Pavlov A.V. Razvitie pravovogo statusa podozrevaemogo $\mathrm{v}$ ugolovnom sudoproizvodstve Rossii [Development of the Legal Status of a Suspect in Russian Criminal Proceedings]. Vestnik Volgogradskoi akademii MVD Rossii, 2018, no. 1, pp. 131-141.
6. Patrusheva A.A. Ugolovno-protsessualnye pravootnosheniia, voznikaiushchie v sviazi so smertiu uchastnikov ugolovnogo sudoproizvodstva: dis. ... kand. yurid. nauk [Criminal Procedural Legal Relations Arising in Connection with the Death of Participants in Criminal Proceedings. Cand. jurid. sci. diss.]. Omsk, 2020. 257 p.

7. Sopneva E.V. Zapodozrennyi kak sposob vyrazheniia podozreniia [Suspected as a Way of Expressing Suspicion]. Aktualnye problemy rossiiskogo prava, 2014, no. 7, pp. 1474-1480.

8. Khorsheva V.S. O nekotorykh aspektakh vzaimodeistviia sledovatelia, doznavatelia $\mathrm{s}$ operativnymi sluzhbami organov vnutrennikh del v khode rassledovaniia prestuplenii [About Some Aspects of the Interaction of the Investigator, the Investigator with the Operational Services of the Internal Affairs Bodies During the Investigation of Crimes]. Vestnik Volgogradskoi akademii MVD Rossii, 2019, no. 1, pp. 166-173.

9. Tsokolova O.I., Karpenko V.M. Dosudebnoe proizvodstvo v otnoshenii umershego podozrevaemogo (obviniaemogo) [Pre-Trial Proceedings Against a Deceased Suspect (Accused)]. Vestnik Moskovskogo universiteta MVD Rossii, 2016, no. 4, pp. 125-130.

10. Shipunova O.V. Smert litsa, sovershivshego prestuplenie, kak osnovanie otkaza v vozbuzhdenii ugolovnogo dela [The Death of a Person Who Committed a Crime as a Basis for Refusing to Initiate a Criminal Case]. Iuridicheskaia nauka $i$ pravookhranitelnaia praktika, 2015, no. 2, pp. 189-195.

11. Ugolovno-protsessualnyi kodeks Respubliki Belarus ot 16.07.1999 № 295-Z (s izmeneniiami i dopolneniiami po sostoianiiu na 17.07.2020) [Criminal Procedure Code of the Republic of Belarus No. 295-Z of July 16, 1999]. IS Paragraf «Iurist». URL: https:// o№liNoe.zakoßo..kz/docume№t/?doc_id=30414958.

12. Ugolovno-protsessualnyi kodeks Respubliki Kazakhstan ot 04.07.2014 № 231-V (s izmeneniiami i dopolneniiami po sostoianiiu na 02.01.2021 g.) [Criminal Procedure Code of the Republic of Kazakhstan No. 231-V of July 4, 2014]. IS Paragraf «Iurist».URL: https://o№li№e.zako№.kz/m/docu meNot?doc_id=31575852.

13. Po delu o proverke konstitutsionnosti stati 6 Ugolovno-protsessualnogo kodeksa RSFSR v sviazi s zhaloboi grazhdanina O.V. Sushkova: postanovlenie KS RF ot 28.10.1996 № 18-P [In the Case of Checking the Constitutionality of Article 6 of the Criminal Procedure Code of the RSFSR in Connection with the Complaint of a Citizen O.V. Sushkov: Resolution of the Constitutional Court of the Russian Federation of 28.10.1996 No. 18-P]. Access from References Legal System 'KonsultantPlyus'.

14. Po delu o proverke konstitutsionnosti polozhenii punkta 4 chasti pervoi stati 24 i punkta 1 stati 254 
Ugolovno-protsessualnogo kodeksa Rossiiskoi Federatsii v sviazi s zhalobami grazhdan S.I. Aleksandrina i Iu.F. Vashchenko: postanovlenie KS RF ot 14.07.2011 № 16-P [In the Case of Checking the Constitutionality of the Provisions of Paragraph 4 of Part One of Article 24 and Paragraph 1 of Article 254 of the Criminal Procedure Code of the Russian Federation in Connection with the Complaints of Citizens S.I. Alexandrin and Yu.F. Vashchenko: Resolution of the Constitutional Court of the Russian Federation of 14.07.2011 No. 16-P]. Access from References Legal System 'KonsultantPlyus'.

15. Ob otkaze v priniatii $\mathrm{k}$ rassmotreniiu zhaloby grazhdanina Zakharova Andreia Valentinovicha na narushenie ego konstitutsionnykh prav punktom 4 chasti pervoi stati 24 Ugolovno-protsessualnogo kodeksa Rossiiskoi Federatsii: opredelenie KS RF ot 10.03.2016 № 456-O [About Refusal in Acceptance for Consideration of the Complaint of the Citizen Zakharov Andrey Valentinovich on Violation of his Constitutional Rights by Point 4 of Part One of Article
24 of the Criminal Procedure Code of the Russian Federation: Definition of the Constitutional Court of the Russian Federation of 10.03.2016 No. 456-O]. Ofitsialnyi sait KS RF. Resheniia KS RF. URL: http:// doc.ksrf.ru/decision/KSRFDecision228376.pdf.

16. Ob otkaze v priniatii $\mathrm{k}$ rassmotreniiu zhaloby grazhdan Zhideleva Dmitriia Konstantinovicha i Kozhevnikova Iuriia Ivanovicha na narushenie ikh konstitutsionnykh prav punktom 4 chasti pervoi stati 24 Ugolovno-protsessualnogo kodeksa Rossiiskoi Federatsii: opredelenie KS RF ot 29.09.2020 № 1944-O [About Refusal in Acceptance for Consideration of the Complaint of Citizens Zhidelev Dmitry Konstantinovich and Kozhevnikov Yuri Ivanovich on Violation of Their Constitutional Rights by Point 4 of Part One of Article 24 of the Criminal Procedure Code of the Russian Federation: Definition of the Constitutional Court of the Russian Federation of 29.09.2020 No. 1944-O]. Ofitsialnyi sait KS RF. Resheniia KS RF. URL: http:// doc.ksrf.ru/decision/KSRFDecision497485.pdf.

\section{Information About the Authors}

Kristina A. Trifonova, Candidate of Sciences (Jurisprudence), Associate Professor, Department of Preliminary Investigation, Educational and Scientific Complex for Preliminary Investigation in the Internal Affairs Bodies, Volgograd Academy of the Ministry of Internal Affairs of Russia, Istoricheskaya St, 130, 400089 Volgograd, Russian Federation, trifonova1102@mail.ru, https://orcid.org/0000-0002-0755-1871

Mikhail A. Shmatov, Doctor of Sciences (Jurisprudence), Professor, Department of Preliminary Investigation, Educational and Scientific Complex for Preliminary Investigation in the Internal Affairs Bodies, Volgograd Academy of the Ministry of Internal Affairs of Russia, Istoricheskaya St, 130, 400089 Volgograd, Russian Federation, vitaliyshmatov@mail.ru, https://orcid.org/0000-0002-1736-704X

Vadim N. Perekrestov, Candidate of Sciences (Jurisprudence), Associate Professor, Justice of the Peace, Judicial District No. 47, Sovetskaya St, 67, 404171 Svetly Yar, Volgograd Region, Russian Federation, perekrestova@volsu.ru, https://orcid.org/0000-0003-3978-5389

\section{Информация об авторах}

Кристина Алексеевна Трифонова, кандидат юридических наук, доцент кафедры предварительного расследования учебно-научного комплекса по предварительному следствию в органах внутренних дел, Волгоградская академия МВД России, ул. Историческая, 130, 400089 г. Волгоград, Российская Федерация, trifonova1102@mail.ru, https://orcid.org/0000-0002-0755-1871

Михаил Андреевич Шматов, доктор юридических, наук, профессор, профессор кафедры предварительного расследования учебно-научного комплекса по предварительному следствию в органах внутренних дел, Волгоградская академия МВД России, ул. Историческая, 130, 400089 г. Волгоград, Российская Федерация, vitaliyshmatov@mail.ru, https://orcid.org/0000-0002-1736-704X

Вадим Николаевич Перекрестов, кандидат юридических наук, доцент, мировой судья, Судебный участок № 47, ул. Советская, 67, 404171 р. п. Светлый Яр, Волгоградская область, Российская Федерация, perekrestova@volsu.ru, https://orcid.org/0000-0003-3978-5389 